\title{
EFFORTS TO IMPROVE LANGUAGE ABILITY THROUGH THINK-TALK-WRITE LEARNING MODEL
}

\author{
Ratna Juita ${ }^{a}$, Mardan ${ }^{b}$ \\ ${ }^{a}$ Teacher at MTS Negeri 2 Kota Bengkulu \\ ${ }^{\mathrm{b}}$ Lecture at Universitas Muhammadiyah Bengkulu \\ *corresponding author : ratnajuita1967@gmail.com
}

\begin{abstract}
Teaching strategies are related to the methods chosen by educators in determining the scope, sequence of discussion, learning activities, and others in delivering material to students in the classroom. In the learning process it is often found that when students are given written assignments, students always try to immediately start writing answers, even though it is not something wrong, but will be more meaningful if first doing thinking activities, reflecting and composing ideas and testing those ideas before starting to write them. The Think-Talk-Write (TTW) model chosen in this study was built by giving students time to do the activity (thinking, reflecting and to compile ideas, and testing the ideas before writing them). Think-Talk-Write learning strategies are an effort to improve language skills. Language elements obtained by using the Think-Talk-Write model are stages of thinking that can foster children's ability in the fields of listening, reading and writing. The stages of talk can be to improve the ability to speak, write, and listen / listen to children. The Write stage can improve listening and writing skills.
\end{abstract}

Key words: language skills, Think-Talk-Write Model

\section{INTRODUCTION}

At the beginning of human creation process, Allah SWT has established human as caliph on earth. This means, implicitly, that human beings bear huge and heavy responsibilities concerning the task of the Caliphate. In this context, Allah revealed His revelation in form of the holy Qur'an to Prophet Muhammad SAW as a source of guidance to lead people to a happy and prosperous life, both in the world and in the hereafter.

In addition to Al-Qur'an as guidance (hidayah book), especially for Muslims and humanity in general, it is also believed to be the book of Allah. That is the Qur'an is not just a "divine revelation" containing God's messages that are sacred and full of absolute value, but more than that, the Qur'an is a set of wisdom and pearls of truth of God's teachings that are "grounded" to guide humanity towards a goal based on its dignity. The study and content of the Qur'an covers various aspects ranging from stories, human history, natural events, human events, natural phenomena, promises and threats, laws, akidah, muamalah, the end of the universe, the fate of humanity in the future, and so forth. All of them are ibrah (lessons) for humans to be good at 
reading situations and conditions. To understand the various types of Al-Qur'an understanding, the first step that must be taken by someone is to read, (Sudaryah, 2015). As the word of God says:

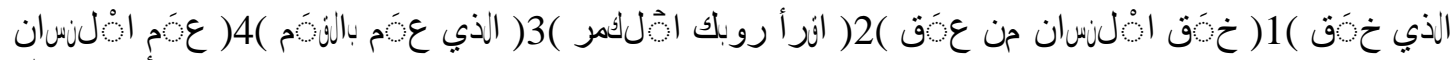

$$
\begin{aligned}
& \text { أقر أ باسم ربك أنَ }
\end{aligned}
$$

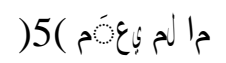

"Recite in the name of your Lord who created. Created man from a clinging substance. Recite, and your Lord is the most Generous. Who taught by the pen. Taught man that which he knew not" (QS. Al 'Alaq: 1-5).

Today, society's language skill, especially reading, is still become a problem for the Indonesian people. This turned out to have an impact including in the academic environment. Indeed, there are other problems that overshadow this condition. Oral culture in Indonesia seems to be still more dominant. Even reading activities for children recently faced challenges because of the rapid development of games and online media culture that is not balanced with reading culture. It is not surprising when someone reads a book, he cannot immediately understand what he is reading until someone explains the contents of the book verbally. So, at the end, the language ability of Indonesian in the community, including the academic community is not encouraging, (Siti Saudah, 2015).

Good writing skill shows good language skills too. When someone is able to write well, this shows three other basic abilities that he has, which are listening, speaking, and reading, and they are quite well-trained. Indonesians' language skills will never be mastered if it is not accompanied by high encouragement and enthusiasm from individual, society, and field of education.

The application of Think-Talk-Write model in schools can be implemented as an alternative so that children can improve their language skills. The learning process with Think-Talk-Write method was introduced by Huinker \& Laughlin. According to them, basically through reading children will start thinking, speaking, and writing. The flow of Think-Talk-Write learning progress begins with child's involvement in thinking or dialogue with himself after the reading process, then talks to share ideas (sharing) with his friends and then put them in writing. In this process, the child plays an active role in the learning process (Saudah, 2015). 


\section{METHOD}

The method used in this study was literature study. This method used to find theoretical references that are relevant to cases or problems discussed in the study. These references can be searched from books, journals, research report articles, and sites on the internet. Literature studies are conducted to enrich references those are relevant to the problem.

\section{RESULTS AND DISCUSSION}

Language Skills

Language is an arbitrary sound symbol system which is used by a social community as a means for communication, cooperation, and self-identification. With language, one may explore the world. With language too, a person could express what in his heart. Language is able to realize one's ideals (Mukhlason, 2013). The science of sociolinguistics argues that language is a social product or cultural product. Thus, language cannot be separated from human culture. Language is also a channel or media for social aspirations, community behavior, and disclosure of culture including technology created by humans as language users (Sumarsono, 2011).

Humans are not only born voiced, but they also have built their sound into language construction, which is subsequently utilized as a vehicle for social interaction in the community or society. In interacting socially, humans communicate by employing language vehicles that are constructed contextually and that have been agreed upon, both in the level of structure and meaning of language (Manuaba, 2013).

Language constitutes a communication device that is essentially, general and public-spirited because in communication there are always two sides involved, namely as material givers and information recipients. The meant information fundamentally can be splitted into two types, specifically as follows:

1. Cognitive information: information which is related to reasoning, like understanding, assumptions, and thoughts about something.

2. Affective information: information which is related to feelings of sadness, pain, solidarity, happiness, and hope.

From the above two functions mentioned, the most dominant one is cognitive functions. Communication has two kinds, namely oral communication and written communication. Based on the communication system, in language skills, there are four skills that must be explored, namely as follows 
1. Listening

2. Speaking

3. Reading

4. Writing

The first two language skills are characterized as oral communication, namely listening and speaking, and the last two language skills are characterized as written communication, namely reading and writing. The sequence of a person's language skill acquisition starts from listening and then talking, reading and lastly is writing. These all sequences are obtained when someone was a child, but when one has reached the age of adulthood, the four language skills acquisition of language have functioned integrally in the sense of mutual support.

\section{(Think-Talk-Write) Model}

The Cooperative learning type model Think Talk Write (TTW) was introduced by Huinker \& Laughlin. Fundamentally, this learning is constructed through the process of thinking, speaking and writing. Think Talk Write (TTW) learning strategies can promote problem solving skills (Yamin and Ansari, 2012). The learning progress flow of TTW starts with the involvement of students in thinking or dialogue by themselves after the reading process, afterward, talking and sharing ideas with their friends before writing.

Above situation is more effective if it is conducted in heterogeneous groups with 3-5 students inside. In this group, students are instructed to read, make small notes, explain, listen and share ideas with friends and further express them through writing, (Riadi. 2014).

This thinking, speaking and writing activities are one of the forms of teaching and learning activities that give the students opportunities to actively participate. The stages, implemented in learning employing this type, are thinking (Think), talking (Talk), and writing (Write).

Teaching strategies are everything related to the methods selected by teachers in determining the scope, discussion sequence, learning activities, and others in conveying materials to students in the classroom. In the learning process, it is frequently found that when students are assigned written assignments, students always try to immediately start writing answers, even though it is not something wrong, but it will be more meaningful if at the beginning, they apply thinking activities, reflecting and composing ideas and testing those ideas before starting to write them. The selected Think-Talk-Write model in this study 
was constructed by giving students time to do those activities (thinking, reflecting and to compile ideas, and testing the ideas before writing them).

Further, Huinker and Laughlin in (Saudah, 2015) splitted the stages as follows:

The first stage activities of students who learn with think-talk-write model is think, namely the stage of thinking where students read the passage in the form of questions. In this stage, the students individually think of possible answers (completion strategies), make small notes about the ideas written in the passage, and / or things that they do not understand matched with the discussion.

The second stage is talk (talking or discussion) gives students opportunities to talk about their inquiry in the first stage. At this stage, students reflect, compile, and test (negotiate, share) ideas in group discussion activities. The communication progress of students will be visible in their dialogue in discussions either in exchanging ideas with other people or their own reflections expressed to others.

The third stage is write, students write down the ideas they achieve from the first and second stage activities. This writing consists of the conceptual basis employed, the linkage with the former materials, the completion strategy, and the gained solutions.

\section{The Application of Think-Talk-Write (TTW) Learning}

The application of the Think-Talk-Write (TTW) learning model is able to upgrade language skills (listening, speaking, reading and writing). This can be described as follows:

1. Listening

Someone normally is already able to hear the sounds produced by anything around them. Nevertheless, as individuals who have latterly begun to grow, whatever is listened cannot be immediately recognized. There is a recognition process to what and who produces sounds. This thing, amazingly, feels well throughout human life, so that we can distinguish who or what pulls out the sound. (https://indonesiasaram.wordpress.com). Think-talk-write (TTW) learning, in listening skill, can be seen in the stages of (1) pre-stages (1), (2) core stage (think, talk, and write stages) until stage of (3) evaluation. This learning indicates an enhancement in listening skill, because children are required to take part actively in their learning process.

2. Speaking

Speaking ability is the next ability that every human being has. This was 
obtained as a form of imitation of the language sound. However, in terms of nonverbal language, speaking ability seems to have been inherent in a person since he was born. This is manifested in the form of crying. From the observations in think talk write (TTW) learning, it can be said that an indicator of speaking ability can be observed from student's activities. At the talk stage (speaking), the child is encouraged to convey his idea because the teacher is active to motivate and guide student to discuss. When students are able to express their ideas through spoken language, the teacher evaluates / monitors them in discussions, and encourages student to participate. Thus the learning of Think-talk-write is able to improve speaking abilities by honing and motivating student to express their ideas through predetermined themes.

\section{Reading}

Reading ability becomes the third ability as the first high level ability before writing. Reading becomes an ability that must be owned by someone well before entering the next stage, namely the ability to write. In Think-talk-write learning, indicators of reading ability are found in the think stage, namely thinking. The ability to read appears when the students are given problems that must be read and thought to be resolved. Thus the teacher guides the student to find solutions to the problems by making notes in their own languages.

4. Able to write

Good writing skills clearly show good language skills. When someone is able to write well, this shows that the other three basic abilities are quite well-trained. Indicators of writing ability in student can be known in the process of think talk write (TTW) learning. At the think-talk-write stage, the students are able to express their ideas or solutions to the problems given through their writings. In this learning, the students are expected to be able to build or construct the knowledge obtained from the previous stages, namely (1) think, the students must make notes on their own language. Stage (2) talk, students are motivated to write group ideas both written and spoken. Stage (3) Write, students are expected to be able to construct problem solving.

Furthermore, the description of the think-talk-write (TTW) learning model, and indicators of language proficiency to be achieved can be explained as in the table below:

The elements of the language proficiency (listening, speaking, reading, and writing) with Think-Talk-Write Learning Model. 


\begin{tabular}{|c|c|c|c|}
\hline No. & $\begin{array}{l}\text { Aspects to be observed } / \\
\text { Observation } \\
\text { Indicators }\end{array}$ & $\begin{array}{l}\text { Students' activities to be } \\
\text { observed }\end{array}$ & $\begin{array}{l}\text { The elements of } \\
\text { language } \\
\text { proficiency }\end{array}$ \\
\hline 1 & $\begin{array}{l}\text { Pre } \text { Activities / Introduction } \\
\text { a. } \quad \text { Motivating student } \\
\text { b. }\end{array}$ & - & $\begin{array}{l}\text { Growing the } \\
\text { Students' ability to } \\
\text { Listen }\end{array}$ \\
\hline 2 & $\begin{array}{l}\text { Main activities } \\
\text { 1. THINK } \\
\text { a. Give questions or } \\
\text { questions to student } \\
\text { b. Recall the approach } \\
\text { that will be used in learning } \\
\text { activities } \\
\text { c. Guide student to make } \\
\text { notes with their own language }\end{array}$ & $\begin{array}{l}\text { 1. THINK } \\
\text { a. Student completing } \\
\text { the question items } \\
\text { b. Student read the } \\
\text { question text } \\
\text { c. Student make notes } \\
\text { to answer questions with } \\
\text { their own language. }\end{array}$ & $\begin{array}{l}\text { This stage can grow } \\
\text { student's abilities in } \\
\text { the area of listening, } \\
\text { reading and writing. }\end{array}$ \\
\hline & $\begin{array}{l}\text { 2. TALK (Speaking) } \\
\text { a. Divide student into } \\
\text { groups, each group of 5 } \\
\text { students with varying levels } \\
\text { of ability. } \\
\text { b. Listen carefully to the } \\
\text { ideas of students. } \\
\text { c. Ask students express } \\
\text { their ideas both spoken and in } \\
\text { written } \\
\text { d. Guide and explore the } \\
\text { results brought by students to } \\
\text { discuss ans and assess } \\
\text { e. Monitor and aricipation in } \\
\text { students' particion } \\
\text { discussions and encourage } \\
\text { them to participate. }\end{array}$ & 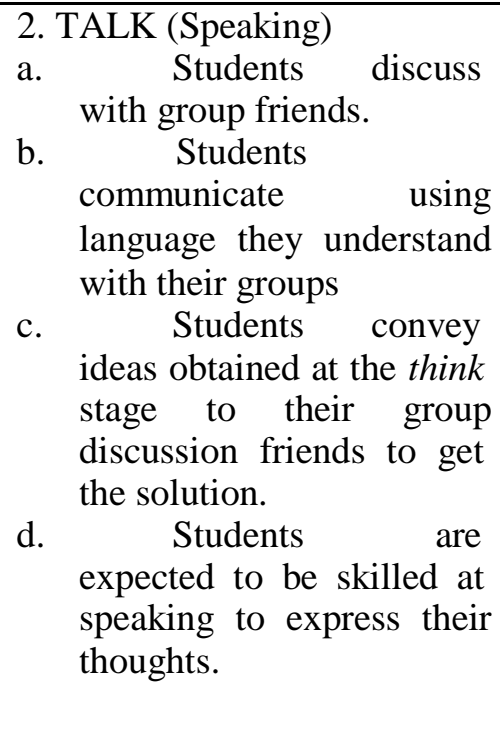 & $\begin{array}{l}\text { Talk Stage is able to } \\
\text { improve the students } \\
\text { ability to speak, write } \\
\text { and listen. }\end{array}$ \\
\hline & $\begin{array}{l}\text { 3. WRITE } \\
\text { a. Guiding and giving } \\
\text { information, classifying } \\
\text { students in solving problems. } \\
\text { b. Helping students in } \\
\text { constructing knowledge in } \\
\text { written form. }\end{array}$ & $\begin{array}{l}\text { 3. WRITE } \\
\text { a. Students take notes } \\
\text { / write the results of the } \\
\text { discussion } \\
\text { b. Students express } \\
\text { ideas after discussion in } \\
\text { written form }\end{array}$ & $\begin{array}{l}\text { In this learning, at the } \\
\text { last stage can improve } \\
\text { ability to listen and } \\
\text { write. }\end{array}$ \\
\hline 3 & Evaluating & - & Listening ability \\
\hline
\end{tabular}

Source: Saudah (2015)

\section{CONCLUSION}

The Think-Talk-Write (TTW) learning model can improve students' language skills. This model can be applied by the teacher in the effort to improve students' learning achievement. Language elements obtained by using the Think-Talk-Write model are stages of think that can foster students' abilities in the areas of listening, 
reading and writing. The stages of talk can improve the students' ability to speak, write, and listen. The write stage can improve students' listening and writing skills.

\section{REFERENCES}

Ansari, B.I. 2003.Menumbuhkembangkan Kemampuan Pemahaman dan Komunikasi Matematik melalui Strategi Think-Talk-Write (Eksperimen di SMUN Kelas I Bandung).Disertasi Doktor pada FPMIPA UPI Bandung: Tidak diterbitkan.

Manuaba, I.B. Putera. 2013. "Politik Bahasa Sastra: Strategi Bahasa Ekspresif Produksi Karya Sastra". Proseding Seminar Nasional Politik Bahasa dan Bahasa Politik. Fakultas Ilmu Budaya. Universitas Airlangga. Surabaya. 25-26 Oktober.

Muhlason, A. dkk., 2013. "Vikinisasi dan Identitas Generasi Muda". Proseding Seminar Nasional Politik Bahasa dan Bahasa Politik. Fakultas Ilmu Budaya. Universitas Airlangga. Surabaya. 25-26 Oktober.

Riadi M. 2014. Model Pembelajaran Kooperatif Thinl Talk Write (TTW) https://www.kajianpustaka.com/2014/02/model-pembelajaran-kooperatif-think.html

Saudah S. 2015. Meningkatkan kemampuan berbahasa (mendengar, berbicara, membaca, menulis) Melalui pembelajaran think-talk-write (TTW). http://repository.akprind.ac.id/sites/files/Makalah\%20Seminar\%20UNESA.p df

Sudaryah. 2015. Membaca dalam perspektif Al-Qur'an. http://digilib.uinsuka.ac.id/19841/2/12530063_BAB-I_IV-atau-V_DAFTAR-PUSTAKA.pdf

Sumarsono. 2011. Sosiolinguistik. Yogyakarta: Pustaka Pelajar.

Yamin, M \& Ansari B.I. 2012. Taktik Mengembangkan Kemampuan Individual Siswa. Jakarta: http://turunanilmu.blogspot.com/2010/12/pengertian-dan-kemampuanberbahasa.html. Diakses pada hari jumat, 6 April 2015 